\title{
Introducing the Mixed Distribution in Fitting Rainfall Data
}

\author{
Jamaludin Suhaila, Kong Ching-Yee, Yusof Fadhilah, Foo Hui-Mean \\ Department of Mathematics, Faculty of Science, University Teknologi Malaysia, Johor Bahru, Malaysia \\ E-mail:suhailasj@utm.my \\ Received July 26, 2011; revised August 29, 2011; accepted September 27, 2011
}

\begin{abstract}
Several types of mixed distribution are proposed and tested in order to determine the best model in describing daily rainfall amount in Peninsular Malaysia for the time period of 33 years. A mixed distribution is a mixture of discrete and continuous daily rainfall which included the dry days. The mixed distributions tested in this study were exponential distribution, gamma distribution, weibull distribution and lognormal distribution. The model will be selected based on the Akaike Information Criterion (AIC). In general, the mixed lognormal distribution has been selected as the best model for most of the rain gauge stations in Peninsular Malaysia. However, these results are greatly influenced by the topographical, geographical and climatic changes of the rain gauge stations.
\end{abstract}

Keywords: Mixed distribution, Akaike Information Criterion (AIC), Maximum Likelihood Estimator (MLE), Mixed Lognormal

\section{Introduction}

Flood and drought are the calamity that can cause by imbalance amount of rainfall and amount of runoff in the certain area. Flood happen when the amount of rainfall is greater than the outflow of water, while drought is vice versa. Both these disasters will give great impact to agriculture sector and cause death if the disaster is seriously befallen. Hence, by studying the characteristic of the rainfall, preparations to overcome these disasters can be done earlier in order to reduce any lose that occur. Hence, continuous researches interested on the distribution of hydrology have been carried out [1-4].

Modelling rainfall data can be distinguished into two parts: rainfall occurrence and rainfall amount. A model of rainfall occurrence is a model that provides a sequence of dry and wet days, while a model of rainfall amounts simulates the amount of rainfall occurring on each wet days [5]. Markov chain models are often used to fit the rainfall occurrence [6,7]. On the other hand, two parameters gamma distribution, exponential distribution, weibull and lognormal are among the theoretical distribution used to fit the rainfall attribute [8-13]. However, gamma distribution only models the amount of rainfall in wet days [14].

In Peninsular Malaysia, studies on finding the best model for rainfall data had been carried out by several researchers. Mixed-exponential is the best fit distribution for hourly rainfall data among exponential, gamma and weibull [15]. While mixed lognormal is the most appropriate distribution for describing the daily rainfall amount compare to lognormal and skew normal [16]. Based on these studies, the mixed distribution is seemed more suitable in describing rainfall data in Peninsular Malaysia. Hence, mixed distributions are more suitable for Peninsular Malaysia [17,18].

However, past studies that have been conducted in Malaysia, only considered rainfall amount on wet days, which does not following the nature of rainfall where there are days that do not rain at all. The importance of included the zeros (dry days) is the characterization of daily rain rate, drought, or climate change effects can by analyze [19]. To the best of author knowledge, the mixtures of two distributions which include the rainfall data for dry days and wet days have not yet been done in Malaysia. Hence the study proposes to investigate the concept of mixture of these rainfall data.

\section{Study Area}

Malaysia is located in Southeast Asia which has two land mass which separated by South China Sea. The land 
mass that on the Asian mainland is called Peninsular Malaysia and the other is East Malaysia with two states Sarawak and Sabah which located on the island of Borneo. The area of Malaysia is approximately 330,000 square kilometres and share border with Thailand (in the north), Singapore, Indonesia (in the south), Brunei and the Philippines (in the east). The weather in Malaysia is generally hot and humid due to its location which near to the equator. The climate between the east and west coasts are different due to two monsoon seasons that annually strike in Malaysia. The southwest monsoon occurs from May to August while the occurrence of northeast monsoon is during November to February. The periods between these two monsoons are named as inter monsoon seasons. Northeast monsoon usually bring heavy rain to east coast of Peninsular Malaysia. Compared to the northeast monsoon, the southwest monsoon is much drier throughout Peninsular Malaysia due to the Peninsular Malaysia is protected by Sumatran (Indonesia) mountain range. During the inter monsoons seasons, the west coast of Peninsular Malaysia will reach the maximum monthly mean rainfall. Generally, the annual rainfall in Malaysia is between the ranges of 2000 to $4000 \mathrm{~mm}$ with uniform temperature which ranged from $25.5^{\circ} \mathrm{C}$ to $32^{\circ} \mathrm{C}$ throughout the country.

\section{Rainfall Data}

The daily rainfall data used in this study were obtained from the Malaysian Meteorological Department and Drainage and Irrigation Department which contain the period of 33 years (1975-2007). Seventy rain gauge stations were chosen for this study. The quality of rainfall data was checked through the homogeneity test, which are the standard normal homogeneity test, Buishand range test, the Pettitt test and the Von Neumann ratio test [20]. The stations chosen were scatter around in the area of Peninsular Malaysia. The details about the stations are shown in Table 1 and Figure 1.

\section{Methodology}

\subsection{Modeling Rainfall Amount}

Most of the data are either discrete or continuous. The characteristic of rainfall data is neither continuous component nor discrete component, but it is a mixture of both components. However, the rainfall data were often assumed as continuous values in which zero rainfall values were ignored. A mixed distribution was suggested by combining the discrete and continuous components [21]. For mixed distribution, given a random sample $X_{1}$, $X_{2}, \cdots, X_{n}$ that containing $n-m$ zeroes (dry days), the likelihood of the random sample with parameter; $p$ and $\theta$ is as follows:

$$
L(p, \theta \mid x)=p^{m}(1-p)^{n-m} f\left(x_{1}, \theta\right) \cdots f\left(x_{m}, \theta\right)
$$

where $m$ is the total of wet days, and $f$ is a parametric family distribution. Equation (1) does not represent the true likelihood if the data are dependent. The MLE of $p$ is given as $\hat{p}=m / n$.

In this study, four mixed distribution model were used to determine the appropriate model for rainfall characteristic in Peninsular Malaysia. The probability density function and the logarithm of the likelihood function of the four distributions will be described with $X$ as the random sample for each distribution.

- Exponential distribution is given as

$$
f(x ; \lambda)=\left\{\begin{array}{cc}
\lambda \mathrm{e}^{-\lambda x}, & x \geq 0 \\
0, & x<0
\end{array}\right.
$$

where $\lambda>0$ is named as rate parameter or the scale parameter which determined the variation of rainfall amount series. By using (1), the likelihood of exponenttial distribution is shown below:

$$
L(p, \lambda \mid x)=p^{m}(1-p)^{n-m} \prod_{i=1}^{m} \lambda \mathrm{e}^{-\lambda x_{i}}
$$

Then, solve the log likelihood function and the MLE for $\hat{\lambda}$ is given as $\hat{\lambda}=1 / \bar{x}$. The same method is applied for others distribution in order to find their log likelihood function and MLE.

- Use e The weibull distribution with two parameters is described as follows:

$$
f(x ; \alpha, \beta)=\left\{\begin{array}{cc}
(\alpha / \beta)(x / \beta)^{\alpha-1} \mathrm{e}^{-(x / \beta)^{\alpha}}, & x \geq 0 \\
0, & x<0
\end{array}\right.
$$

where $\alpha>0$ is the shape parameter and $\beta>0$ is the scale parameter. Shape parameter represents the shape of the distribution and scale parameter determines the variation of rainfall amount series.

The logarithm of the likelihood function of mixed weibull is given as below

$$
\begin{aligned}
\ln L\left(p, \alpha, \beta \mid x_{i}\right)= & m \ln p+(n-m) \ln (1-p) \\
& +m \ln \alpha-m \alpha \ln \beta+(\alpha-1) \sum_{i=1}^{m} \ln x_{i} \\
& -\sum_{i=1}^{m}\left(x_{i} / \beta\right)^{\alpha}
\end{aligned}
$$

To solve the nonlinear equation, the method known as Simple Iterative Procedure is employed [22].

- The probability density function for gamma distribution can be written as

$$
f(x ; \alpha, \beta)=\left(\beta^{-\alpha} x^{\alpha-1} / \Gamma(\alpha)\right) \mathrm{e}^{-x / \beta} \text { for } x>0
$$


Table 1. The latitude and longitude of the chosen 70 stations.

\begin{tabular}{|c|c|c|c|}
\hline Code & Station Name & Latitude & Longitude \\
\hline E01 & Kota Bharu & $6^{\circ} 10^{\prime} 12^{\prime \prime} \mathrm{N}$ & $102^{\circ} 16^{\prime} 48^{\prime \prime} \mathrm{E}$ \\
\hline E02 & To' Uban & $5^{\circ} 58^{\prime} 12^{\prime \prime} \mathrm{N}$ & $102^{\circ} 08^{\prime} 24^{\prime \prime} \mathrm{E}$ \\
\hline E03 & Sek. Keb. Kg. Jabi & $5^{\circ} 40^{\prime} 48^{\prime \prime} \mathrm{N}$ & $102^{\circ} 33^{\prime} 36^{\prime \prime} \mathrm{E}$ \\
\hline E04 & Kg. Merang, Setiu & $5^{\circ} 31^{\prime} 48^{\prime \prime} \mathrm{N}$ & $102^{\circ} 57^{\prime} 00^{\prime \prime} \mathrm{E}$ \\
\hline E05 & Stor JPS Kuala Trengganu & $5^{\circ} 19^{\prime} 12^{\prime \prime} \mathrm{N}$ & $103^{\circ} 07^{\prime} 48^{\prime \prime} \mathrm{E}$ \\
\hline E06 & Kg. Menerong & $4^{\circ} 56^{\prime} 24^{\prime \prime} \mathrm{N}$ & $103^{\circ} 03^{\prime} 36^{\prime \prime} \mathrm{E}$ \\
\hline E07 & Klinik Bidan, Jambu Bongkok & $4^{\circ} 56^{\prime} 24^{\prime \prime} \mathrm{N}$ & $103^{\circ} 21^{\prime} 00^{\prime \prime} \mathrm{E}$ \\
\hline E08 & Sek.Men. Sultan Omar, Dungun & $4^{\circ} 45^{\prime} 36^{\prime \prime} \mathrm{N}$ & $103^{\circ} 25^{\prime} 12^{\prime \prime} \mathrm{E}$ \\
\hline E09 & Sek. Keb. Kemasek & $4^{\circ} 25^{\prime} 48^{\prime \prime} \mathrm{N}$ & $103^{\circ} 27^{\prime} 00^{\prime \prime} \mathrm{E}$ \\
\hline E10 & JPS Kemaman & $4^{\circ} 13^{\prime} 48^{\prime \prime} \mathrm{N}$ & $103^{\circ} 25^{\prime} 12^{\prime \prime E}$ \\
\hline E11 & Kuantan & $3^{\circ} 46^{\prime} 48^{\prime \prime} \mathrm{N}$ & $103^{\circ} 13^{\prime} 12^{\prime \prime} \mathrm{E}$ \\
\hline E12 & Rumah Pam Pahang Tua, Pekan & $3^{\circ} 33^{\prime} 36^{\prime \prime} \mathrm{N}$ & $103^{\circ} 21^{\prime} 36^{\prime \prime} \mathrm{E}$ \\
\hline E13 & Endau & $2^{\circ} 35^{\prime} 24^{\prime \prime} \mathrm{N}$ & $103^{\circ} 40^{\prime} 12^{\prime \prime E}$ \\
\hline E14 & Mersing & $2^{\circ} 27^{\prime} 00^{\prime \prime} \mathrm{N}$ & $103^{\circ} 49^{\prime} 48^{\prime \prime} \mathrm{E}$ \\
\hline NW01 & Abi Kg. Bahru & $6^{\circ} 30^{\prime} 36^{\prime \prime} \mathrm{N}$ & $100^{\circ} 10^{\prime} 48^{\prime \prime} \mathrm{E}$ \\
\hline NW02 & Guar Nangka & $6^{\circ} 28^{\prime} 48^{\prime \prime} \mathrm{N}$ & $100^{\circ} 16^{\prime} 48^{\prime \prime} \mathrm{E}$ \\
\hline NW03 & Padang Katong ,Kangar & $6^{\circ} 27^{\prime} 00^{\prime \prime} \mathrm{N}$ & $100^{\circ} 11^{\prime} 24^{\prime \prime E}$ \\
\hline NW04 & Arau & $6^{\circ} 25^{\prime} 48^{\prime \prime} \mathrm{N}$ & $100^{\circ} 16^{\prime} 12^{\prime \prime} \mathrm{E}$ \\
\hline NW05 & Kodiang & $6^{\circ} 22^{\prime} 12^{\prime \prime} \mathrm{N}$ & $100^{\circ} 18^{\prime} 00^{\prime \prime} \mathrm{E}$ \\
\hline NW06 & Alor Star & $6^{\circ} 12^{\prime} 00^{\prime \prime} \mathrm{N}$ & $100^{\circ} 24^{\prime} 00^{\prime \prime} \mathrm{E}$ \\
\hline NW07 & Ampang Pedu & $6^{\circ} 14^{\prime} 24^{\prime \prime} \mathrm{N}$ & $100^{\circ} 46^{\prime} 12^{\prime \prime} \mathrm{E}$ \\
\hline NW08 & Pendang & $5^{\circ} 59^{\prime} 24^{\prime \prime} \mathrm{N}$ & $100^{\circ} 28^{\prime} 48^{\prime \prime} \mathrm{E}$ \\
\hline NW09 & SIK & $5^{\circ} 48^{\prime} 36^{\prime \prime} \mathrm{N}$ & $100^{\circ} 43^{\prime} 48^{\prime \prime} \mathrm{E}$ \\
\hline NW10 & Dispensari Kroh & $5^{\circ} 42^{\prime} 36^{\prime \prime} \mathrm{N}$ & $101^{\circ} 00^{\prime} 00^{\prime \prime} \mathrm{E}$ \\
\hline NW11 & Rumah Pam Bumbong Lima & $5^{\circ} 33^{\prime} 36^{\prime \prime} \mathrm{N}$ & $100^{\circ} 26^{\prime} 24^{\prime \prime} \mathrm{E}$ \\
\hline NW12 & Bkt Berapit & $5^{\circ} 22^{\prime} 48^{\prime \prime} \mathrm{N}$ & $100^{\circ} 28^{\prime} 48^{\prime \prime} \mathrm{E}$ \\
\hline NW13 & Ldg. Batu Kawan & $5^{\circ} 15^{\prime} 36^{\prime \prime} \mathrm{N}$ & $100^{\circ} 25^{\prime} 48^{\prime \prime} \mathrm{E}$ \\
\hline NW14 & Klinik Bkt. Bendera & $5^{\circ} 25^{\prime} 12^{\prime \prime} \mathrm{N}$ & $100^{\circ} 16^{\prime} 12^{\prime \prime} \mathrm{E}$ \\
\hline NW15 & Kolam Takongan Air Itam & $5^{\circ} 24^{\prime} 00^{\prime \prime} \mathrm{N}$ & $100^{\circ} 16^{\prime} 12^{\prime \prime} \mathrm{E}$ \\
\hline NW16 & Pintu A.Bagan, Air Itam & $5^{\circ} 21^{\prime} 00^{\prime \prime} \mathrm{N}$ & $100^{\circ} 12^{\prime} 00^{\prime \prime} \mathrm{E}$ \\
\hline NW17 & Rumah Penjaga JPS. Parit Nibong & $5^{\circ} 07^{\prime} 48^{\prime \prime} \mathrm{N}$ & $100^{\circ} 30^{\prime} 36^{\prime \prime} \mathrm{E}$ \\
\hline SW01 & Jam. Sg. Simpangn, Jln. Empat & $2^{\circ} 26^{\prime} 24^{\prime \prime} \mathrm{N}$ & $102^{\circ} 11^{\prime} 24^{\prime \prime E}$ \\
\hline SW02 & Malacca & $2^{\circ} 16^{\prime} 12^{\prime \prime N}$ & $102^{\circ} 15^{\prime} 00^{\prime \prime} \mathrm{E}$ \\
\hline SW03 & Pekan Merlimau & $2^{\circ} 09^{\prime} 00^{\prime \prime} \mathrm{N}$ & $102^{\circ} 25^{\prime} 48^{\prime \prime} \mathrm{E}$ \\
\hline
\end{tabular}




\begin{tabular}{|c|c|c|c|}
\hline SW04 & Ldg. Bkt. Asahan & $2^{\circ} 23^{\prime} 24^{\prime \prime} \mathrm{N}$ & $102^{\circ} 33^{\prime} 00^{\prime \prime} \mathrm{E}$ \\
\hline SW05 & Tangkak & $2^{\circ} 15^{\prime} 00^{\prime \prime N}$ & $102^{\circ} 34^{\prime} 12^{\prime \prime} \mathrm{E}$ \\
\hline SW06 & Pintu Kawalan Separap Batu Pahat & $1^{\circ} 55^{\prime} 12^{\prime \prime} \mathrm{N}$ & $102^{\circ} 52^{\prime} 48^{\prime \prime} \mathrm{E}$ \\
\hline SW07 & Pintu Kawalan Sembrong & $1^{\circ} 52^{\prime} 48^{\prime \prime} \mathrm{N}$ & $103^{\circ} 03^{\prime} 00^{\prime \prime} \mathrm{E}$ \\
\hline SW08 & Sek.Men.Inggeris Batu Pahat & $1^{\circ} 52^{\prime} 12^{\prime \prime} \mathrm{N}$ & $102^{\circ} 58^{\prime} 48^{\prime \prime} \mathrm{E}$ \\
\hline SW09 & Ldg. Kian Hoe, Kluang & $2^{\circ} 01^{\prime} 48^{\prime \prime} \mathrm{N}$ & $103^{\circ} 16^{\prime} 12^{\prime \prime} \mathrm{E}$ \\
\hline SW10 & Kluang & $2^{\circ} 01^{\prime} 12^{\prime \prime} \mathrm{N}$ & $103^{\circ} 19^{\prime} 12^{\prime \prime} \mathrm{E}$ \\
\hline SW11 & Ldg. Benut, Rengam & $1^{\circ} 50^{\prime} 24^{\prime \prime} \mathrm{N}$ & $103^{\circ} 21^{\prime} 00^{\prime \prime} \mathrm{E}$ \\
\hline SW12 & Ibu Bekalan Kahang, Kluang & $2^{\circ} 13^{\prime} 48^{\prime \prime} \mathrm{N}$ & $103^{\circ} 36^{\prime} 00^{\prime \prime} \mathrm{E}$ \\
\hline SW13 & Sek.Men.Bkt Besar di Kota Tinggi & $1^{\circ} 45^{\prime} 36^{\prime \prime} \mathrm{N}$ & $103^{\circ} 43^{\prime} 12^{\prime \prime} \mathrm{E}$ \\
\hline SW14 & Senai & $1^{\circ} 37^{\prime} 48^{\prime \prime} \mathrm{N}$ & $103^{\circ} 40^{\prime} 12^{\prime \prime} \mathrm{E}$ \\
\hline SW15 & Ldg. Getah Kukup, Pontian & $1^{\circ} 21^{\prime} 00^{\prime \prime} \mathrm{N}$ & $103^{\circ} 27^{\prime} 36^{\prime \prime} \mathrm{E}$ \\
\hline SW16 & Stor JPS Johor Bahru & $1^{\circ} 28^{\prime} 12^{\prime \prime} \mathrm{N}$ & $103^{\circ} 45^{\prime} 00^{\prime \prime} \mathrm{E}$ \\
\hline W01 & Stn. Pemereksaan Hutan, Lawin & $5^{\circ} 18^{\prime} 00^{\prime \prime N}$ & $101^{\circ} 0336 " \mathrm{E}$ \\
\hline W02 & Selama & $5^{\circ} 08^{\prime} 24^{\prime \prime} \mathrm{N}$ & $100^{\circ} 42^{\prime} 00^{\prime \prime} \mathrm{E}$ \\
\hline W03 & Rumah JPS, Alor Pongsu & $5^{\circ} 03^{\prime} 00^{\prime \prime} \mathrm{N}$ & $100^{\circ} 35^{\prime} 24 " \mathrm{E}$ \\
\hline W04 & Pusat Kesihatan Bt.Kurau & $4^{\circ} 58^{\prime} 48^{\prime \prime} \mathrm{N}$ & $100^{\circ} 48^{\prime} 00^{\prime \prime} \mathrm{E}$ \\
\hline W05 & Gua Musang & $4^{\circ} 52^{\prime} 48^{\prime \prime} \mathrm{N}$ & $101^{\circ} 58^{\prime} 12^{\prime \prime} \mathrm{E}$ \\
\hline W06 & Ipoh & $4^{\circ} 34^{\prime} 12^{\prime \prime} \mathrm{N}$ & $101^{\circ} 06^{\prime} 00^{\prime \prime} \mathrm{E}$ \\
\hline W07 & Ldg Boh & $4^{\circ} 27^{\prime} 00^{\prime \prime} \mathrm{N}$ & $101^{\circ} 25^{\prime} 48^{\prime \prime} \mathrm{E}$ \\
\hline W08 & S. K. Kg. Aur Gading & $4^{\circ} 21^{\prime} 00^{\prime \prime} \mathrm{N}$ & $101^{\circ} 55^{\prime} 12^{\prime \prime} \mathrm{E}$ \\
\hline W09 & Sitiawan & $4^{\circ} 13^{\prime} 12^{\prime \prime} \mathrm{N}$ & $100^{\circ} 42^{\prime} 00^{\prime \prime} \mathrm{E}$ \\
\hline W10 & Rumah Kerajaan JPS, Chui Chak & $4^{\circ} 03^{\prime} 00^{\prime \prime} \mathrm{N}$ & $101^{\circ} 10^{\prime} 12^{\prime \prime} \mathrm{E}$ \\
\hline W11 & Rumah Pam Paya Kangsar & $3^{\circ} 54^{\prime} 00^{\prime \prime} \mathrm{N}$ & $102^{\circ} 25^{\prime} 48^{\prime \prime} \mathrm{E}$ \\
\hline W12 & Ibu Bekalan Sg. Bernam & $3^{\circ} 42^{\prime} 00^{\prime \prime} \mathrm{N}$ & $101^{\circ} 21^{\prime} 00^{\prime \prime} \mathrm{E}$ \\
\hline W13 & Kg. Sg. Tua & $3^{\circ} 16^{\prime} 12^{\prime \prime} \mathrm{N}$ & $101^{\circ} 41^{\prime} 24 " \mathrm{E}$ \\
\hline W14 & Gombak & $3^{\circ} 16^{\prime} 12^{\prime \prime} \mathrm{N}$ & $101^{\circ} 43^{\prime} 48^{\prime \prime} \mathrm{E}$ \\
\hline W15 & Empangan Genting Kelang & $3^{\circ} 14^{2} 24^{\prime \prime N}$ & $101^{\circ} 45^{\prime} 00^{\prime \prime} \mathrm{E}$ \\
\hline W16 & JPS. Wilayah Persekutu & $3^{\circ} 09^{\prime} 36^{\prime \prime} \mathrm{N}$ & $101^{\circ} 40^{\prime} 48^{\prime \prime} \mathrm{E}$ \\
\hline W17 & Genting Sempah & $3^{\circ} 22^{\prime} 12^{\prime \prime} \mathrm{N}$ & $101^{\circ} 46^{\prime} 12^{\prime \prime} \mathrm{E}$ \\
\hline W18 & Janda Baik & $3^{\circ} 19^{\prime} 48^{\prime \prime} \mathrm{N}$ & $101^{\circ} 51^{\prime} 36 " \mathrm{E}$ \\
\hline W19 & Sg.Lui Halt & $3^{\circ} 04^{\prime} 48^{\prime \prime} \mathrm{N}$ & $102^{\circ} 22^{\prime} 12^{\prime \prime} \mathrm{E}$ \\
\hline W20 & Ldg. Sg. Sabaling & $2^{\circ} 51^{\prime} 00^{\prime \prime} \mathrm{N}$ & $102^{\circ} 29^{\prime} 24^{\prime \prime} \mathrm{E}$ \\
\hline W21 & Setor JPS Sikamat Seremban & $2^{\circ} 44^{\prime} 24^{\prime \prime N}$ & $101^{\circ} 57^{\prime} 36 " \mathrm{E}$ \\
\hline W22 & Hospital Port Dickson & $2^{\circ} 31^{\prime} 48^{\prime \prime} \mathrm{N}$ & $101^{\circ} 48^{\prime} 00^{\prime \prime} \mathrm{E}$ \\
\hline W23 & Ldg. Sengkang & $2^{\circ} 25^{\prime} 48^{\prime \prime} \mathrm{N}$ & $101^{\circ} 57^{\prime} 36 " \mathrm{E}$ \\
\hline
\end{tabular}


THE LOCATION OF THE RAIN GAUGE STATIONS IN PENINSULAR MALAYSIA

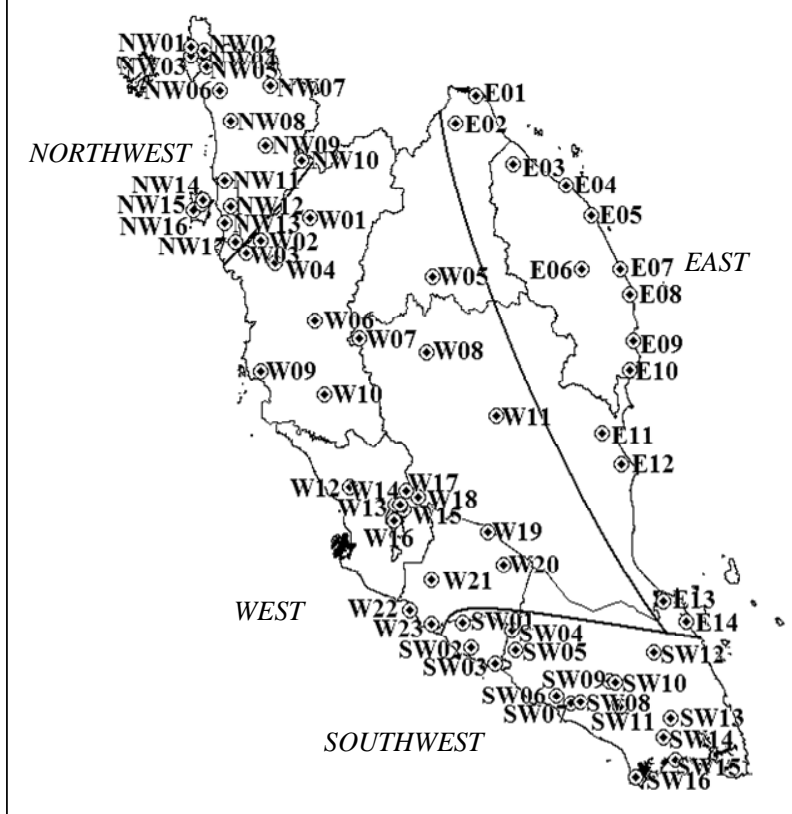

Figure 1. The location of the 70 rain gauge stations in Peninsular Malaysia.

where $\alpha>0$ is the shape parameter and $\beta>0$ is the scale parameter for gamma distribution.

The logarithm of the likelihood function of mixed gamma is given as

$$
\begin{aligned}
\ln L\left(p, \alpha, \beta \mid x_{i}\right)= & m \ln p+(n-m) \ln (1-p) \\
& +(\alpha-1) \sum_{i=1}^{m} \ln x_{i}-m \alpha \ln \beta \\
& -m \ln \Gamma(\alpha)-(1 / \beta) \sum_{i=1}^{m} x_{i}
\end{aligned}
$$

where the MLE for $\hat{\beta}$ is $\hat{\beta}=\bar{x} / \hat{\alpha}$ while the MLE for $\hat{\alpha}$ is $\psi(\alpha)=\left(\sum_{i=1}^{m} \ln x_{i} / m\right)-\ln \beta$ which

$\psi(\alpha)=\Gamma^{\prime}(\alpha) / \Gamma(\alpha)$ is the digamma function.

- The probability density function for lognormal distribution is

$$
f(x ; \mu, \sigma)=(1 / x \sigma \sqrt{2 \pi}) \mathrm{e}^{\left[-(\ln x-\mu)^{2} / 2 \sigma^{2}\right]} \text { for } x>0
$$

where $\mu$ and $\sigma$ are the location and scale parameters respectively.

\subsection{Goodness-of-Fit Tests (GOF)}

GOF is used to determine the best model among the distributions tested in rain characteristic. In this study, AIC was used to select the best model. The model that attains the lowest AIC will be the best model among the com- petitive distribution. The result of AIC is directly dependent with the sample size of observation [23]. AIC is asymptotically effective and unbiased since the test is based on the maximum likelihood function and if the sample size is sufficiently larger than 30 , the test will yield fairly accurate result [24]. The sample size of this study is greater than 30 , hence AIC can be applied to determine the best model. The formula for AIC is given as

$$
A I C=-2 \ln L+2 k
$$

where $\ln L$ is the logarithm of the likelihood function of the propose model and $k$ is the number of parameters.

\section{Result and Discussion}

This section is divided into two main sub-sections. The descriptive statistics for each of the seventy rain gauge stations will be discussed in the first sub-section followed by a discussion on fitting distributions in the second sub-sections.

\subsection{Descriptive Statistics}

The descriptive statistics in terms of mean, standard deviation, coefficient of variations (CV), skewness, the maximum amount of rainfall and number of wet days of the annual rainfall amount for each seventy rain gauge stations are summarized in Table 2 . Based on the values of descriptive statistics, the five highest mean rainfall amounts among the stations are Chui Chak (W10), followed by $\mathrm{Kg}$ Menerong (E06), Endau (E13), Selama (W02) and Pusat Kesihatan Bt. Kurau (W04). Due to the geographical locations of Selama, Chui Chak and Bt. Kurau stations which full of limestone bedrock, granitic hills and mine waste deposits (e.g. slime, tailings and mining ponds) [25].

Lake is an indicator of high level climate and mountain also can affect the climate in the area [26]. These situations somehow contribute to the increase in total amount of rainfall in those areas. Lawin (W01), Ldg. Sg.Sabaling (W20), Raya Kangsar (W11), Guar Nangka (NW02) and Sitiawan (W09) are among the stations that received the lowest mean rainfall. Most of these stations are at the inland areas of Peninsular Malaysia in which the climate at these areas is less affected by the monsoons. The climate for most of the inland stations is relatively dry [27].

In terms of CV, three of the stations (W12, W10 and SW09 stations) attain the highest CV among the other stations which in the range of $28 \%$ to $45 \%$. These results the irregularity of the daily rainfall received by the stations. On the other hand, the value of skewness is affect 
Table 2. Statistic of annual rainfall amount for seventy rain gauge stations.

\begin{tabular}{|c|c|c|c|c|c|}
\hline Code Station & Mean & CV (\%) & Skewness & $\begin{array}{l}\text { Maximum amount } \\
\text { of rainfall }(\mathrm{mm})\end{array}$ & $\begin{array}{l}\text { Number of } \\
\text { Wet Days }\end{array}$ \\
\hline E01 & 2514.17 & 23.74 & 5.99 & 591.5 & 4378 \\
\hline E02 & 2711.21 & 26.72 & 4.95 & 409 & 4632 \\
\hline E03 & 2782.36 & 17.83 & 3.93 & 329.5 & 4487 \\
\hline E04 & 2740.71 & 20.13 & 3.97 & 365.5 & 3884 \\
\hline E05 & 2574.25 & 16.63 & 5.33 & 520.4 & 4623 \\
\hline E06 & 3572.57 & 22.77 & 6.67 & 676 & 6245 \\
\hline E07 & 2491.53 & 13.6 & 8.49 & 790 & 3814 \\
\hline E08 & 2492.8 & 18.43 & 5.02 & 572 & 4599 \\
\hline E09 & 2610.47 & 15.78 & 4.21 & 330 & 4365 \\
\hline E10 & 2662.02 & 13.7 & 4.88 & 434 & 4796 \\
\hline E11 & 2910.43 & 18.71 & 4.99 & 527.5 & 4947 \\
\hline E12 & 2522.35 & 16.49 & 5.04 & 444.8 & 4447 \\
\hline E13 & 3192.49 & 17.28 & 3.98 & 353.5 & 5313 \\
\hline E14 & 2624.81 & 23.22 & 4.91 & 383.3 & 4890 \\
\hline NW01 & 1891.97 & 16.77 & 2.63 & 125.5 & 4522 \\
\hline NW02 & 1741.53 & 15.86 & 3.15 & 218.5 & 4274 \\
\hline NW03 & 1895.09 & 17.4 & 2.6 & 150.1 & 4482 \\
\hline NW04 & 1967.99 & 20.17 & 2.51 & 180 & 4389 \\
\hline NW05 & 1902.01 & 20.08 & 2.66 & 163 & 4531 \\
\hline NW06 & 1971.59 & 16.28 & 2.56 & 172.1 & 4493 \\
\hline NW07 & 2018.02 & 26.46 & 2.79 & 211.5 & 4665 \\
\hline NW08 & 2222.72 & 21.89 & 3.12 & 261 & 4865 \\
\hline NW09 & 2594.84 & 23.61 & 2.71 & 220.5 & 5043 \\
\hline NW10 & 2062.3 & 18.37 & 2.6 & 175 & 5084 \\
\hline NW11 & 2139.28 & 21.67 & 3.32 & 275 & 4339 \\
\hline NW12 & 2182.73 & 26.49 & 3.79 & 295 & 4650 \\
\hline NW13 & 1837.35 & 14.96 & 2.67 & 206 & 3872 \\
\hline NW14 & 2764.42 & 13.96 & 4.35 & 484.8 & 5199 \\
\hline NW15 & 2258.85 & 18.72 & 3.67 & 308.5 & 4917 \\
\hline NW16 & 2506.14 & 20.88 & 2.59 & 245.5 & 4270 \\
\hline NW17 & 2187.5 & 15.13 & 2.75 & 230 & 3584 \\
\hline SW01 & 2371.15 & 23.61 & 2.44 & 217.5 & 4990 \\
\hline SW02 & 1980.71 & 17.73 & 2.86 & 275.2 & 4428 \\
\hline SW03 & 1964.88 & 14.51 & 3.22 & 272.5 & 4168 \\
\hline
\end{tabular}




\begin{tabular}{|c|c|c|c|c|c|}
\hline SW04 & 1769.56 & 13.27 & 2.3 & 172 & 3550 \\
\hline SW05 & 1895.45 & 19.86 & 2.29 & 152.7 & 4366 \\
\hline SW06 & 1910.17 & 14.28 & 2.33 & 137.5 & 3963 \\
\hline SW07 & 2146.75 & 17.92 & 3.64 & 320 & 4811 \\
\hline SW08 & 2222.21 & 18.83 & 2.86 & 200.5 & 4623 \\
\hline SW09 & 1929.68 & 29.96 & 2.27 & 210 & 3087 \\
\hline SW10 & 2116.02 & 22.68 & 4.82 & 433.4 & 4767 \\
\hline SW11 & 2199.05 & 19.49 & 2.87 & 210 & 4550 \\
\hline SW12 & 2760.32 & 12.71 & 4.31 & 372 & 5395 \\
\hline SW13 & 2076.83 & 22.13 & 3.64 & 271.5 & 5012 \\
\hline SW14 & 2447.37 & 11.5 & 4.21 & 364.4 & 5369 \\
\hline SW15 & 2467.35 & 20.55 & 3.39 & 260 & 4797 \\
\hline SW16 & 2407.34 & 15.92 & 3.3 & 313.6 & 5132 \\
\hline W01 & 1682.42 & 14.76 & 2.82 & 159 & 4586 \\
\hline W02 & 3165.87 & 13.75 & 2.01 & 176 & 5400 \\
\hline W03 & 2417.88 & 17.95 & 2.52 & 170 & 5187 \\
\hline W04 & 3151.77 & 16.42 & 2.21 & 193 & 6435 \\
\hline W05 & 2331.09 & 22.48 & 2.57 & 154.5 & 5544 \\
\hline W06 & 2487.51 & 14.74 & 2.08 & 135.4 & 5248 \\
\hline W07 & 2187.79 & 12.55 & 2.27 & 110 & 6481 \\
\hline W08 & 2315.17 & 15.07 & 2.1 & 130 & 4077 \\
\hline W09 & 1760.24 & 18.42 & 2.67 & 178.7 & 4251 \\
\hline W10 & 3590.15 & 31.11 & 1.36 & 160.5 & 4926 \\
\hline W11 & 1733.74 & 10.85 & 3.58 & 259.8 & 4314 \\
\hline W12 & 2548.82 & 44.89 & 2.29 & 173.6 & 5274 \\
\hline W13 & 2386.12 & 20.17 & 2.39 & 173.5 & 5317 \\
\hline W14 & 2421.35 & 15.89 & 2.13 & 139 & 5297 \\
\hline W15 & 2354.28 & 14.87 & 2.22 & 162.5 & 5233 \\
\hline W16 & 2577.83 & 17.34 & 2.66 & 289 & 5425 \\
\hline W17 & 2483.4 & 13.88 & 16.46 & 800.5 & 6018 \\
\hline W18 & 1863.52 & 24.28 & 3.47 & 210 & 5044 \\
\hline W19 & 2182.01 & 20.9 & 2.3 & 215 & 3111 \\
\hline W20 & 1722.8 & 13.58 & 3.19 & 226 & 3936 \\
\hline W21 & 1974.31 & 16.71 & 2.37 & 144.5 & 4674 \\
\hline W22 & 1997.41 & 18.88 & 2.77 & 200 & 4209 \\
\hline W23 & 2148.78 & 14.36 & 4.8 & 500 & 3922 \\
\hline
\end{tabular}


by maximum amount of rainfall received by the stations. For example, the Genting Sempah (W17) station has the both highest maximum amount and skewness value. While in terms of number of wet days, rain always occurred at these areas. In addition, there is study indicated that the landslide often occur at area of Genting Sempah which had caused numbers of deaths and injuries [28]. Hence, some studies had been carried out to predict the landslide hazard [29] and debris flow [30] in Genting Sempah.

Due to the effect of northeast monsoon, the stations (E01, E02, E03, E04, E05, E06, E07, E08, E09, E10, E12, E13, E14, SW12 and W22 stations) that are at the east coast of Peninsular Malaysia receive high mean rainfall amount which are more than $2490 \mathrm{~mm}$. Besides, the stations (NW14, NW15 and NW16 stations) located in island take in more rainfall amount than the stations (NW11, NW12 and NW13 stations) in mainland although the location of these stations are in the same neighborhood. Not only that, the stations (W12, W13, W14, W15 and W16 stations) situated in urban area also receive high rainfall amount. Hence, rainfall amount can be varying according to the surrounding of the area and monsoons.

\subsection{Fitting Distribution Based on AIC Criterion}

The results of AIC values are displayed in Table 3 with the bolded values indicated the lowest AIC. The best fit distribution of the rain gauge stations are shown in Figure 2. The mixed lognormal distribution is dominating other distributions as the best fitting distribution among the studied stations. 48 stations attained the lowest AIC values for mixed lognormal followed by 20 stations chosen for mixed gamma to describe their rainfall data. On the other hand, only 2 stations chose mixed weibull as the best fitting distribution. Of all distributions, the mixed exponential was never selected by any of the stations.

Most of the stations that are located at the east coast obtain mixed gamma distribution as their best model. It is possible that the distributions of rainfall data at these stations are influenced by the northeast monsoon flow.

Meanwhile the Chui Chak station (W10) and Sg. Lui Halt station (W19) are the only two stations acquired mixed weibull distribution as the most appropriate fitted distribution. These stations are located at the foot of the mountain and recorded relatively high mean rainfall amount, high in coefficient variation, low in skewness and low in maximum amount of rainfall. These characteristics of rainfall data may possibly suitable for the chosen fitted distribution.

In general, the distinction of elevation and the expo-

\section{THE BEST FIT DISTRIBUTION OF THE RAIN GAUGE} STATIONS IN PENINSULAR MALAYSIA

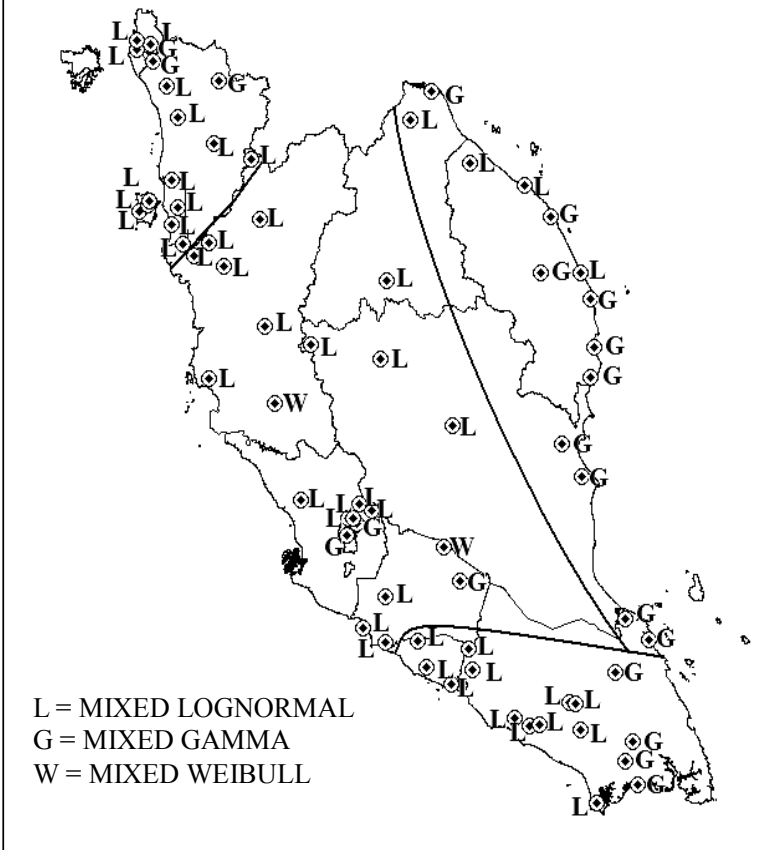

Figure 2. The best fit distribution of the $\mathbf{7 0}$ rain gauge stations in Peninsular Malaysia.

sure of the stations towards southwest and northeast monsoons could give impact in the result of the fitting of the distribution. The geographical sites, climatic changes and topographical of the stations also will be strongly affect the result.

\section{Conclusions}

The urge in finding the most appropriate fitting distribution for daily rainfall amount in Peninsular Malaysia is always the main interest in particular studies. The concept of included zero values into rainfall data for attain the best fit distribution in Peninsular Malaysia still commence among researchers in Malaysia. Several distributions have been tested and compare in this study to find the best fitting distribution. The distributions tested are mixed exponential, mixed gamma, mixed weibull and mixed lognormal distributions.

The mixed lognormal distribution was the preferred best fitted distribution for the majority of the stations in Peninsular Malaysia which determined by Akaike Information Criterion. Mixed gamma distribution was the second favoured distribution followed by mixed weibull distribution. A big number of the stations in the east coast of Peninsular Malaysia were identifying mixed gamma distribution as the most appropriate distribution. 
Table 3. The AIC Values of each of the seventy rain gauge stations.

\begin{tabular}{|c|c|c|c|c|}
\hline Code Station & Mixed Lognormal & Mixed Exponential & Mixed Weibull & Mixed Gamma \\
\hline E01 & 1780.2 & 1836.12 & 1819.75 & 1776.57 \\
\hline E02 & 1935.18 & 1966.82 & 1966.66 & 1965.91 \\
\hline E03 & 1859.61 & 1875.44 & 1875.71 & 1903.17 \\
\hline E04 & 2026.01 & 2088.15 & 2077.12 & 2052.49 \\
\hline E05 & 2192.14 & 2302.2 & 2245.2 & 2147.35 \\
\hline E06 & 3618.95 & 3719.17 & 3687.61 & 3591.95 \\
\hline E07 & 2180.86 & 2219.33 & 2221.1 & 2238.46 \\
\hline E08 & 2500.94 & 2590.35 & 2561.57 & 2490.82 \\
\hline E09 & 2531.7 & 2627.46 & 2592.58 & 2523.7 \\
\hline E10 & 2920.32 & 3042.57 & 2992.85 & 2889.33 \\
\hline E11 & 3000.91 & 3085.3 & 3058.61 & 2981.49 \\
\hline E12 & 2804.99 & 2915.33 & 2871.41 & 2778.78 \\
\hline E13 & 3187.37 & 3287.68 & 3246.43 & 3140.35 \\
\hline E14 & 2525.02 & 2586.52 & 2567.61 & 2511.59 \\
\hline NW01 & 1195.13 & 1221.16 & 1221.71 & 1224.53 \\
\hline NW02 & 1163.38 & 1194.62 & 1188.05 & 1168.29 \\
\hline NW03 & 1116.84 & 1126.51 & 1127.13 & 1120.45 \\
\hline NW04 & 1149.66 & 1172.35 & 1168.25 & 1148.9 \\
\hline NW05 & 1163.8 & 1182.11 & 1178.05 & 1156.64 \\
\hline NW06 & 1042.91 & 1051.43 & 1052.91 & 1052.21 \\
\hline NW07 & 1037.51 & 1048.67 & 1047.9 & 1036.71 \\
\hline NW08 & 1296.41 & 1313.28 & 1312.91 & 1304.15 \\
\hline NW09 & 1648.16 & 1676.94 & 1677.45 & 1679.63 \\
\hline NW10 & 2147.8 & 2178.05 & 2178.58 & 2179.74 \\
\hline NW11 & 1886.3 & 1896.38 & 1898.38 & 1910.33 \\
\hline NW12 & 2612.54 & 2639.22 & 2639.25 & 2635.19 \\
\hline NW13 & 2374.93 & 2378.72 & 2380.04 & 2404.06 \\
\hline NW14 & 2028.27 & 2053.87 & 2052.09 & 2037.62 \\
\hline NW15 & 2063.86 & 2095.01 & 2093.17 & 2078.96 \\
\hline NW16 & 1785.7 & 1798.41 & 1800.39 & 1815.03 \\
\hline NW17 & 2528.99 & 2558.74 & 2559.3 & 2594.77 \\
\hline SW01 & 2721.3 & 2739.43 & 2741.09 & 2750.8 \\
\hline SW02 & 2671.64 & 2705.31 & 2705.67 & 2705.72 \\
\hline SW03 & 2455.27 & 2465.63 & 2467.24 & 2492.7 \\
\hline
\end{tabular}




\begin{tabular}{|c|c|c|c|c|}
\hline SW04 & 2473.73 & 2486.84 & 2488.7 & 2497.16 \\
\hline SW05 & 2441.66 & 2473.87 & 2474.51 & 2476.97 \\
\hline SW06 & 2921.51 & 2931.74 & 2931.54 & 2970.96 \\
\hline SW07 & 3207.96 & 3240.12 & 3241.3 & 3249.62 \\
\hline SW08 & 3623.89 & 3640.73 & 3642.52 & 3624.41 \\
\hline SW09 & 1936.21 & 1950.77 & 1951.47 & 1949.19 \\
\hline SW10 & 2713.08 & 2750.38 & 2745.72 & 2720.64 \\
\hline SW11 & 2782.9 & 2804.38 & 2806.36 & 2829.98 \\
\hline SW12 & 3096.57 & 3143.79 & 3125.71 & 3053.59 \\
\hline SW13 & 2727.8 & 2771.99 & 2757.7 & 2697.99 \\
\hline SW14 & 3098.69 & 3128.57 & 3124.44 & 3092.5 \\
\hline SW15 & 3407.23 & 3429.43 & 3428.52 & 3480.96 \\
\hline SW16 & 3181.77 & 3203.63 & 3200.96 & 3174.26 \\
\hline W01 & 2211.82 & 2243.58 & 2244.1 & 2247.44 \\
\hline W02 & 3745.16 & 3770.63 & 3772.11 & 3813.83 \\
\hline W03 & 3319.98 & 3361.06 & 3357.32 & 3335.01 \\
\hline W04 & 4038.2 & 4047.06 & 4048.97 & 4076.01 \\
\hline W05 & 2801.42 & 2832.51 & 2834.45 & 2857.5 \\
\hline W06 & 3637.63 & 3657.88 & 3659.5 & 3669.78 \\
\hline W07 & 3612.07 & 3642.85 & 3644.75 & 3680.64 \\
\hline W08 & 2894.37 & 2920.65 & 2913.8 & 2965.79 \\
\hline W09 & 2617.55 & 2657.16 & 2656.14 & 2649.82 \\
\hline W10 & 2968.49 & 2990.87 & 2960.74 & 2996.41 \\
\hline W11 & 2842.54 & 2871.85 & 2873.85 & 2900.59 \\
\hline W12 & 3673.74 & 3700.92 & 3699.17 & 3683.17 \\
\hline W13 & 3130.36 & 3166.75 & 3165.12 & 3153.22 \\
\hline W14 & 2785.77 & 2817.34 & 2816.9 & 2809.3 \\
\hline W15 & 2886.01 & 2944.01 & 2930.3 & 2878.02 \\
\hline W16 & 3686.22 & 3731.25 & 3720.09 & 3659.66 \\
\hline W17 & 3458.86 & 3485.79 & 3487.67 & 3520.3 \\
\hline W18 & 3022.74 & 3054.46 & 3051.82 & 3105.33 \\
\hline W19 & 2298.48 & 2303.94 & 2279.13 & 2306.98 \\
\hline W20 & 2528.13 & 2557.14 & 2552.91 & 2524.27 \\
\hline W21 & 2660.66 & 2700.23 & 2694.04 & 2662.35 \\
\hline W22 & 2237.97 & 2261.93 & 2263.43 & 2270.58 \\
\hline W23 & 2236.53 & 2253.76 & 2254.63 & 2253.97 \\
\hline
\end{tabular}


These stations are greatly influenced by northeast monsoon. Mixed exponential distribution is the only distribution that has not been selected by any of the stations in describing the rainfall distribution. In conclusion, the rain gauge stations in Peninsular Malaysia are greatly swayed by their topographical, geographical sites and climatic changes which give great disparity on the rainfall distribution.

\section{Acknowledgements}

Authors are faithfully appreciate the generously of the staff of Malaysian Meteorological Department and Drainage and Irrigation Department for providing the daily rainfall data for the usage of this paper. The work is financed by Zamalah Scholarship provided by Universiti Teknologi Malaysia and FRGS vote 4F024 from the Ministry of Higher Education of Malaysia.

\section{References}

[1] V. P. Singh, "On Application of the Weibull Distribution in Hydrology," Water Resources Management, Vol. 1, No. 1, 1987, pp. 33-43. doi:10.1007/BF00421796

[2] R. T. Clarke, "Estimating Trends in Data from the Weibull and a Generalized Extreme Value Distribution," Water Resources Research, Vol. 38, No. 6, 2002, 1089. doi:10.1029/2001WR000575

[3] P. K. Bhunya, R. Berndtsson, C. S. P. Ojha and S. K. Mishra, "Suitability of Gamma, Chi-Square, Weibull, and Beta distributions as Synthetic Unit Hydrographs," Journal of Hydrology, Vol. 334, No. 1-2, 2007, pp. 28-38. doi:10.1016/j.jhydrol.2006.09.022

[4] P. K. Swamee, "Near Lognormal Distribution," Journal of Hydrologic Engineering, Vol. 7, No. 6, 2002, pp. 441-444. doi:10.1061/(ASCE)1084-0699(2002)7:6(441)

[5] T. G. Chapman, "Stochastic Models for Daily Rainfall in the Western Pacific," Mathematics and Computers in Simulation, Vol. 43, No. 3-6, 1997, pp. 351-358. doi:10.1016/S0378-4754(97)00019-0

[6] S. Deni, A. Jemain and K. Ibrahim, "Fitting Optimum Order of Markov Chain Models for Daily Rainfall OccurRences in Peninsular Malaysia," Theoretical and Applied Climatology, Vol. 97, No. 1, 2009, pp. 109-121. doi:10.1007/s00704-008-0051-3

[7] R. D. Stern and R. Coe, "A Model Fitting Analysis of Daily Rainfall Data," Journal of the Royal Statistical Society. Series A (General), Vol. 147, No. 1, 1984, pp. 1-34. doi: $10.2307 / 2981736$

[8] N. T. Ison, A. M. Feyerherm and L. Dean Bark, "Wet Period Precipitation and the Gamma Distribution," Journal of Applied Meteorology, Vol. 10, No. 4, 1971, pp. 658-665.

doi:10.1175/1520-0450(1971)010<0658:WPPATG>2.0. $\mathrm{CO} ; 2$

[9] T. A. Buishand, "Some Remarks on the Use of Daily
Rain-Fall Models," Journal of Hydrology, Vol. 36, No. 3-4, 1978, pp. 295-308.

doi:10.1016/0022-1694(78)90150-6

[10] W. May, "Variability and Extremes of Daily Rainfall during the Indian Summer Monsoon in the Period 1901-1989," Global and Planetary Change, Vol. 44, No. 1-4, 2004, pp. 83-105.

doi:10.1016/j.gloplacha.2004.06.007

[11] H. K. Cho, K. P. Bowman and G. R. North, "A Comparison of Gamma and Lognormal Distributions for Characterizing Satellite Rain Rates from the Tropical Rainfall Measuring Mission," Journal of Applied Mete- orology, Vol. 43, No. 11, 2004, pp. 1586-1597. doi:10.1175/JAM2165.1

[12] S. R. Bhakar, A. K. Bansal, N. Chhajed and R. C. Purohit, "Frequency Analysis of Consecutive Days Maximum Rain-Fall at Banswara, Rajasthan, India," ARPN Journal of Engineering and Applied Sciences, Vol. 1, No. 3, 2006, pp. 64-67.

[13] D. A. Mooley, "Gamma Distribution Probability Model for Asian Summer Monsoon Monthly Rainfall," Monthly Weather Review, Vol. 101, No. 2, 1973, pp. 160-176. doi:10.1175/1520-0493(1973)101<0160:GDPMFA>2.3. $\mathrm{CO} ; 2$

[14] H. Aksoy, "Use of Gamma Distribution in Hydrological Analysis," Turkish Journal of Engineering and Environmental Sciences, Vol. 24, No. 6, 2000, pp. 419-428.

[15] Y. Fadhilah, M. Zalina, V. T. V. Nguyen, S. Suhaila and Y. Zulkifli, "Fitting the Best-Fit Distribution for the Hourly Rainfall Amount in the Wilayah Persekutuan," Jurnal Teknologi, Vol. 46, No. C, 2007, pp. 49-58.

[16] J. Suhaila and A. A. Jemain, "Fitting Daily Rainfall Amount in Malaysia Using the Normal Transform Distribution," Journal of Applied Sciences, Vol. 7, No. 14, 2007, pp. 1800-1886.

[17] J. Suhaila and A. A. Jemain, "Fitting Daily Rainfall Amount in Peninsular Malaysia Using Several Types of Exponential Distributions," Journal of Applied Sciences Research, Vol. 3, No. 10, 2007, pp. 1027-1036.

[18] J. Suhaila and A. A. Jemain, "Fitting the Statistical Distribution for Daily Rainfall in Peninsular Malaysia Based on AIC Criterion," Journal of Applied Sciences Research, Vol. 4, No. 12, 2008, pp. 1846-1857.

[19] E. Ha and C. Yoo, "Use of Mixed Bivariate Distributions for Deriving Inter-Station Correlation Coefficients of Rain Rate," Hydrological Processes, Vol. 21, No. 22, 2007, pp. 3078-3086. doi:10.1002/hyp.6526

[20] J. B. Wijngaard, A. M. G. K. Tank and G. P. K. Nnen, "Homogeneity of 20th Century European Daily Temperature and Precipitation Series," International Journal of Climatology, Vol. 23, No. 6, 2003, pp. 679-692. doi:10.1002/joc. 906

[21] B. Kedem, L. S. Chiu and G. R. North, "Estimation of Mean Rain Rate Application to Satellite Observations," Journal of Geophysical Research, Vol. 95, No. D2, 1990, pp. 1965-1972. doi:10.1029/JD095iD02p01965

[22] H. Qiao and C. P. Tsokos, "Parameter Estimation of the 
Weibull Probability Distribution," Mathematics and Computers in Simulation, Vol. 37, No. 1, 1994, pp. 47-55. doi:10.1016/0378-4754(94)90058-2

[23] R. P. McDonald, "An Index of Goodness-of-Fit Based on Noncentrality," Journal of Classification, Vol. 6, No. 1, 1989, pp. 97-103. doi:10.1007/BF01908590

[24] F. M. Mutua, "The Use of the Akaike Information Criterion in the Identification of an Optimum Flood Frequency Model," Hydrological Sciences Journal, Vol. 39, No. 3, 1994, pp. 235-244. doi:10.1080/02626669409492740

[25] B. K. Tan, "Urban Geology of Kuala Lumpur and Ipoh, Malaysia," International Association of Engineering Geology (IAEG2006), The Geological Society of London, London, 2006, pp. 1-7.

[26] C. E. Vincent, T. D. Davies and A. K. C. Beresford, "Recent Changes in the Level of Lake Naivasha, Kenya, As an Indicator of Equatorial Westerlies over East Africa," Climatic Change, Vol. 2, No. 2, 1979, pp. 175-189. doi:10.1007/BF00133223

[27] W. L. Dale, “The Rainfall of Malaya, Part II," Journal of
Tropical Geography, Vol. 14, 1960, pp.11-28.

[28] Z. A. Roslan and A. H. Zulkifli, "'ROM Scale for Forecasting Erosion Induced Landslide Risk on Hilly Terrain,” In: Kyoji Sassa, Ed., Landslides: Risk Analysis and Sustainable Disaster Management: Proceedings of the Fist General Assembly of the International Consortium on Landslides, Part 3, International Consortium on Landslides, Springer, Berlin Heidelberg, 2005, pp. 197-202.

[29] S. Ahmad, M. I. S. Mohd and M. Hashim, "Application of Remote Sensing Techniques for Prediction of Landslide Hazard Areas in Malaysia," 14th United Nations/International Astronomical Federation Workshop on "Capacity Building in Space Technology for the Benefit of Developing Countries," with an Emphasis on Natural Disaster Management, Vancouver, 2-3 October 2004.

[30] B. K. Tan and W. H. Ting, "Some Case Studies on Debris Flow in Peninsular Malaysia," In: H. Liu, A. Deng, and J. Chu, Eds., Geotechnical Engineering for Disaster Mitigation and Rehabilitation, Springer, Berlin, 2008, pp. 231-235. doi:10.1007/978-3-540-79846-0_20 